\title{
Glutamate Excretion Mechanism in Corynebacterium glutamicum: Triggering by Biotin Starvation or by Surfactant Addition
}

\author{
By YVES CLÉMENT AND GILBERT LANÉELLE* \\ Centre de Recherches de Biochimie et Génétique Cellulaires du CNRS, Université Paul Sabatier \\ \& Groupement Scientifique de Microbiologie, 118 route de Narbonne, F-31062 Toulouse cedex, \\ France
}

(Received 28 October 1985 ; revised 13 December 1985)

Cells of an industrial strain of the L-glutamate producer Corynebacterium glutamicum grown in biotin-starvation conditions lost $30 \%$ of their membrane phospholipids. This was accompanied by a progressive decrease in the rate of accumulation of glutamate and of the intracellular glutamate accumulated at the plateau. Addition of an acylated surfactant to growing cultures of the same strain also induced a progressive loss of glutamate uptake, without changing the $K_{\mathrm{T}}$ of the process. The surfactant-treated cells almost completely excreted the labelled glutamate loaded during a preincubation. These results, together with those obtained previously, allow us to propose that glutamate excretion is mediated by a glutamate permease, after uncoupling of this uptake system resulting from a marked loss of membrane phospholipids. This loss of phospholipids can be induced either by biotin starvation or by addition of an acylated surfactant to growing cells.

\section{INTRODUCTION}

Glutamate excretion by industrial strains of Corynebacterium glutamicum, or by related organisms, is triggered in industrial conditions by inducing modifications of the cell membrane (Demain \& Birnbaum, 1968). In early industrial processes, fatty acid synthesis was impaired by biotin starvation of biotin-auxotrophic strains (Shiio et al., 1962). Since the 1960s, glutamate excretion has been obtained by adding a surfactant, acylated with saturated fatty acids, to exponentially growing cultures: the exogenous fatty acids are incorporated into the lipids (Takinami et al., 1968), de-novo fatty acid synthesis is inhibited and the cells lose nearly half of their membrane lipids (Huchenq et al., 1984).

In a previous paper (Clément et al., 1984) we showed that the acylated surfactant induced selective uncoupling of the glutamate uptake system, and it was postulated that glutamate was excreted via the uncoupled glutamate permease. It is not known if the uncoupling was due to alteration of the permease directly by the added surfactant, or to the observed membrane modifications. We therefore examined the effect of biotin starvation on the membrane lipid content and on glutamate uptake. Parallel experiments were done with surfactant-treated cells to complete our previous results and to compare further the influence of the two excretionpromoting conditions on the cell membrane.

\section{METHODS}

Chemicals. ${ }^{14} \mathrm{C}$-labelled $\mathrm{L}$-glutamate and $\mathrm{L}$-serine were purchased from the Commissariat à l'Energie Atomique (CEA Saclay, France) and [ ${ }^{32}$ P]phosphate from Amersham.

Polyoxyethyleneglycol stearate (Simulsol M49), subsequently called 'acylated surfactant', was obtained from Seppic-Montanoir (Paris, France).

Abbreviation: CCCP, carbonyl cyanide $m$-chlorophenylhydrazone. 
Bacterial growth. The strain of Corynebacterium glutamicum used was obtained from a glutamate-producing company, and was described in our previous work (Clément et al., 1984). Cells were grown in Erlenmeyer flasks on

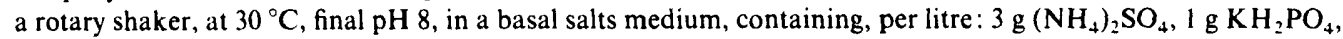
$3 \mathrm{~g} \mathrm{~K}_{2} \mathrm{HPO}_{4}, 0.1 \mathrm{~g} \mathrm{MgSO}_{4} .7 \mathrm{H}_{2} \mathrm{O}, 1 \mathrm{mg} \mathrm{CaCl}, 8.5 \mathrm{mg} \mathrm{ZnSO} \mathrm{Zn}_{4} .7 \mathrm{H}_{2} \mathrm{O}, 72 \mathrm{mg} \mathrm{MnCl}_{2} .4 \mathrm{H}_{2} \mathrm{O}$ and $37 \mathrm{mg}$ $\left(\mathrm{NH}_{4}\right)_{2} \mathrm{MoO} 4$. For normal growth the basal medium was supplemented with $30 \mu \mathrm{g}$ biotin, $100 \mu \mathrm{g}$ thiamin, $4.5 \mathrm{~g}$ urea and $20 \mathrm{~g}$ sucrose per litre. For biotin starvation, the same supplements were added, but only $0 \cdot 3 \mu \mathrm{g}$ biotin.

The acylated surfactant was added at a concentration of $0.5 \%(\mathrm{v} / \mathrm{v})$ to cultures with an $\mathrm{OD}_{650}$ of about 5 units (as measured with a Zeiss PMQ III spectrophotometer), corresponding to $1 \mathrm{mg}$ cell dry weight $\mathrm{ml}^{-1}$.

Amino acid uptake. Collecting of cells and amino acid uptake procedures have been described (Clément $e t$ al., 1984). Three to five uptake experiments were performed for each experimental condition (Figs 2 to 5).

Lipid analysis. Lipids were extracted from sedimented cells or from culture samples and analysed according to our usual procedures (Huchenq et al., 1984). ${ }^{32} \mathrm{P}$ Incorporation into lipids was followed in five independent experiments with the same result.

\section{RESULTS AND DISCUSSION \\ Effects of biotin starvation}

It was checked that biotin starvation did not significantly change the cell fatty acid composition (not shown). It can be concluded from Fig. $1(a)$ that once growth has been inhibited by biotin starvation (Fig. $1 b$ ), the cells lose about one-third of their phospholipids. As stated in the Introduction, the same phenomenon was observed when an acylated surfactant was added to the culture.

The activities of the glutamate and serine uptake systems were followed for normal and biotin-starved cultures during growth (Fig. 2). The activity of the serine uptake system was studied for reference, because it depends on the protonmotive force for its energy, as does the glutamate uptake system (Clément et al., 1984). As long as the cells were actively growing (Fig. $2 a, b$ ), biotin starvation did not alter the activity of the two uptake systems (as seen from amino acid accumulation over $5 \mathrm{~min}$ ), but a slightly lower accumulation plateau was reached in starved cells. This could be due to a lowering of the protomotive force. Clearcut differences between the uptake systems of normal and of starved cells appeared for cells harvested at the beginning of the stationary growth phase (Fig. $2 c, d$ ). The activity of both uptake systems was lowered by biotin starvation, but whereas there was nearly a $75 \%$ decrease in the activity of the glutamate uptake system, there was only a $50 \%$ decrease in the activity of the serine uptake system. Differences at the accumulation plateau were even greater. It can be concluded that, as observed for the effect of an acylated surfactant (Clément et al., 1984), the glutamate uptake system was more impaired by the membrane modification than was the serine uptake system.

\section{Effects of an acylated surfactant}

The above-noted progressive inhibition of glutamate uptake by biotin starvation raised the possibility of the existence of similar kinetics for the effect of the acylated surfactant. As seen in Fig. 3, the maximum inhibition of glutamate uptake was reached after $30 \mathrm{~min}$ growth in the presence of the surfactant. This corresponds to the maximum effect of the surfactant on the cell phospholipid content (Huchenq et al., 1984). In contrast to the effect of biotin starvation, the acylated surfactant did not impair the serine uptake system (Clément et al., 1984), and did not modify the growth curve. The velocity $\left(V_{\max }\right)$ of the uptake was reduced by the acylated surfactant, but the constant $K_{\mathrm{T}}$ was not changed since the four $K_{\mathrm{T}}$ determinations performed with normal and with starved cells were between $2 \times 10^{-5}$ and $3 \times 10^{-5} \mathrm{M}$. Thus, it is likely that the surfactant did not significantly alter the binding site of the substrate on the permease.

To be able to excrete glutamate, the permease has to interact with the glutamate at the inner face of the bacterial membrane. We checked that this was possible by showing that non-treated cells were able to exchange the accumulated amino acid for non-labelled glutamate added in the medium (Fig. 4). The exchange process was even more efficient in decreasing the $\left[{ }^{14} \mathrm{C}\right]$ glutamate content of the cells than was the addition of an uncoupler. Such an exchange process has been described for Escherichia coli (Cohen \& Rickenberg, 1956; Kepes, 1971) for molecules accumulated by the protonmotive force. 


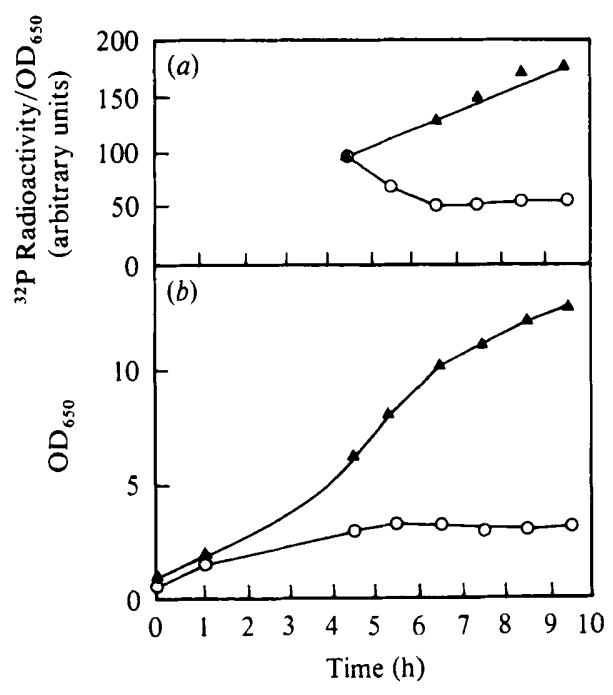

Fig. 1

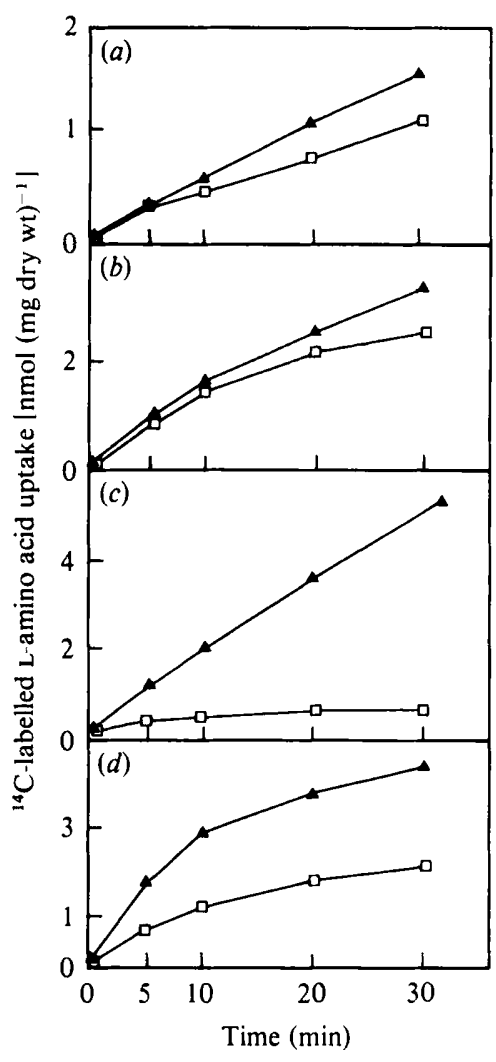

Fig. 2

Fig. 1. ${ }^{32} \mathrm{P}$ incorporation into lipids of normal and biotin-starved cells. (a) Labelling of lipids extracted from $0.8 \mathrm{ml}$ samples of the cultures. Crude counts were corrected for culture growth by dividing them by the culture $\mathrm{OD}_{650}$ and expressed as percentages of the values for the first sample of each of the two cultures (samples taken after $4.5 \mathrm{~h}$ growth; crude counts of $130 \mathrm{c.p} . \mathrm{m}$. and $460 \mathrm{c} . \mathrm{p} . \mathrm{m}$. were obtained for normal and starved cells, respectively, in the experiment presented). In the experiment presented, there were $0.25 \times 10^{6}$ and $5 \times 10^{6}$ c.p.m. per $\mathrm{ml}$ of medium for normal and low biotin cultures, respectively. (b) Growth curves of the cultures. $\boldsymbol{\Delta}$, Normal culture; $\bigcirc$, biotin-starved culture.

Fig. 2. Activity of the L-glutamate and of the L-serine uptake systems in normal and biotin-starved cells. (a) Glutamate uptake of cells harvested during the exponential growth phase; $(b)$ serine uptake of the same cells as in $(a)$. (c) Glutamate uptake of cells harvested during the transition between the exponential and the stationary growth phases; $(d)$ serine uptake of the same cells as in $(c)$. $\boldsymbol{\Delta}$, Control cells; $\square$, biotin-starved cells.

Excretion of accumulated glutamate was then looked for by loading normal or surfactanttreated cells with labelled glutamate, then diluting them in a medium without glutamate (Fig. 5). It appeared that $20 \mathrm{~min}$ after the dilution step, surfactant-treated cells retained only $15 \%$ of their initial labelled glutamate content. The control, non-treated cells doubled their labelling within $20 \mathrm{~min}$ of dilution. This showed that the surfactant-treated cells, but not the control cells, were able to excrete glutamate efficiently.

\section{Conclusion}

The above results, together with those obtained previously (Clément et al., 1984) indicate that glutamate excretion is triggered by a large decrease in the phospholipid content of the bacterial membrane observed on either biotin starvation or surfactant treatment of cells. The resulting membrane alterations selectively uncouple the glutamate uptake system from its energy source, 


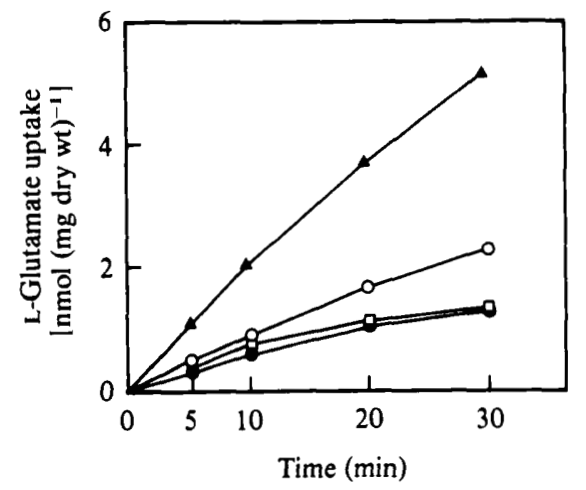

Fig. 3. L-Glutamate uptake by cells grown for different times in the presence of the acylated surfactant. Uptake was followed for control cells $(\boldsymbol{\Delta})$ or for cells grown in the presence of the acylated surfactant for $15 \mathrm{~min}(\mathrm{O}), 30 \mathrm{~min}(\square)$ or $60 \mathrm{~min}(\mathrm{O})$.

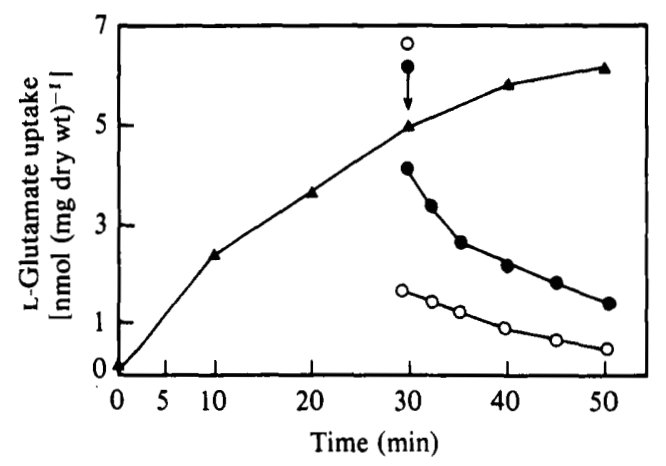

Fig. 4

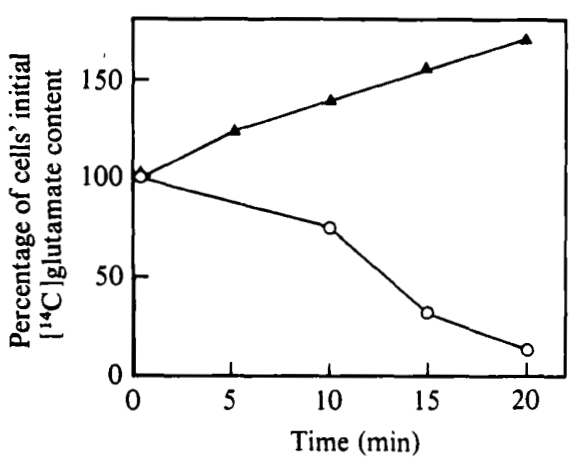

Fig. 5

Fig. 4. Exchange ability of the L-glutamate uptake system. Cells were first allowed to accumulate L$\left[{ }^{14} \mathrm{C}\right]$ glutamate under standard conditions (see Methods). At the time indicated by the arrow the following additions were made : non-labelled L-glutamate at a final concentration five times higher than the labelled L-glutamate $(O)$; an uncoupler $(C C C P, 10 \mu \mathrm{M})(O) . \Delta$, Control.

Fig. 5. L-Glutamate excretion by preloaded cells. Cells were loaded for $30 \mathrm{~min}$ with L- $\left[{ }^{14} \mathrm{C}\right]$ glutamate ( $25 \mu \mathrm{M}$ final concentration), then $0.1 \mathrm{ml}$ of the cell suspension was diluted in $0.9 \mathrm{ml}$ of the transport medium without glutamate. The radioactivity of cells was followed in $0.1 \mathrm{ml}$ samples. The measured values were expressed as percentages of the radioactivity values of samples taken immediately after the dilution step in the non-radioactive medium (time 0 ). In the experiment presented these $100 \%$ values were $36 \times 10^{6}$ and $16 \times 10^{6} \mathrm{c} . \mathrm{p} . \mathrm{m}$. (mg dry weight) ${ }^{-1}$ for normal cells and surfactant-treated cells, respectively. $\Delta$, Non-treated cells (control); $O$, cells grown for $30 \mathrm{~min}$ in the presence of the acylated surfactant.

the protonmotive force, but apparently without impairing the ability of the permease to interact with its substrate. Once uncoupled, the glutamate permease carries the substrate according to its electrochemical potential, i.e. by excreting glutamate from actively growing cells.

The authors thank Dr M. C. Trombe for fruitful discussions and helpful advice. 


\section{REFERENCES}

Clément, Y., Escoffier, B., Trombe, M. C. \& LANÉELLE, G. (1984). Is glutamate excreted by its uptake system in Corynebacterium glutamicum? A working hypothesis. Journal of General Microbiology 130, 2589-2594.

COHEN, G. \& Rickenberg, H. (1956). Concentration spécifique réversible des amino acides chez Escherichia coli. Annales de l'Institut Pasteur 91, 693-720.

Demain; A. L. \& BirnBaum, M. J. (1968). Alteration of permeability for the release of metabolites from microbial cells. Current Topics in Microbiology 46, 1$2 \dot{5}$.

Huchenq, A., Marquet, M., Welby, M., Montrozier, H., Goma, G. \& LANÉelle, G. (1984).
Glutamate excretion triggering mechanism : a reinvestigation of the surfactant-induced modification of cell lipids. Annales de microbiologie 135B, 53-67.

KEPES, A. (1971). Specific transport systems in microorganisms. Physiologie végétale 9, 11-23.

ShIIo, I., OTsuka, S. \& TAKaHAShI, M. (1962). Effect of biotin on the bacterial formation of glutamic acid. I. Glutamate formation and cellular permeability of amino acids. Journal of Biochemistry 51, 56-62.

Takinami, K., Yoshi, H., Yamada, Y., OKada, H. \& Kinoshita, K. (1968). Control of L-glutamic acid fermentation by biotin and fatty acids. Amino Acid and Nucleic Acid 18, 120-156. 